\title{
Use of hybrid debt early redemption during the financial crisis
}

\author{
Marszałek, Jakub
}

- ReCEIVEd: 18 September 2015

- ACCePted: 28 nOVEMBER 2015

\begin{abstract}
The goal of the paper is to analyse the changes in financing conditions of enterprises using convertible bonds, especially those enhanced by the early redemption call/put option. The study was conducted over two periods: before and after the global financial crisis outbreak. The paper has been hypothesized, confirming the use of the call/put option to raise capital on better terms compared to traditional hybrid debt. The study involved the major characteristics of convertible bonds issued by US non-financial corporations before and after the crisis of 2008. To evaluate the differences between the characteristics of bonds, statistical analysis based on significant differences test, $t$-test for independent samples, the Mann-Whitney test and two-factor analysis of variance were employed. The analysis shows that the worse the economic conditions, the shorter the debt maturity, conversion time and conversion premiums. An increased conversion ratio was also observed. These changes, however, are lower for bonds enhanced by the call/put option. This means that the financial crisis has worsened the conditions of hybrid financing. The call/put option eased this change by reducing the financial distress between the company and investors.
\end{abstract}

\section{Keywords:}

Convertible bond, Call/put option, Financial crisis, Capital structure, American company.

\section{JEL classification:}

G23, G32. 


\section{La utilización de la amortización anticipada durante la crisis financiera}

Marszałek, Jakub

\section{Resumen}

El objetivo de este artículo es el análisis de los cambios en las condiciones de financiación de las empresas que utilizan bonos convertibles con cláusula de rescate anticipada a favor del emisor/tenedor (opción de compra/venta implícita). El estudio se ha llevado a cabo en dos periodos temporales: antes y después del estallido de la crisis financiera. El objetivo del mismo es la confirmación de que la utilización de la cláusula de rescate anticipado da lugar a mejores condiciones en la captación de capital que la deuda híbrida tradicional. En el análisis llevado a cabo se han incluido las características más importantes de los bonos convertibles emitidos por las empresas no financieras americanas, antes y después de la crisis de 2008. Se han utilizado diferentes tests estadísticos para contrastar la igualdad de las características de los bonos: test de diferencias significativas, test $t$ para muestras independientes y test de Mann-Whitney; también se ha llevado a cabo un análisis de la varianza de dos factores. De los resultados obtenidos se desprende que las peores condiciones económicas llevaron a vencimientos de la deuda, periodos de conversión y primas de conversión más cortos; se observó también un incremento en la ratio de conversión. Sin embargo, los cambios observados se amortiguaron en el caso de los bonos con cláusulas de rescate anticipado o, en otros términos, opciones de compra/venta implícitas. Esto significa que la crisis financiera ha empeorado las condiciones de financiación híbrida y que la opción de compra/venta implícita calmó esta situación al reducir la problemática financiera entre la empresa y los inversores.

\section{Palabras clave:}

Bono convertible, opción de compra/venta, crisis financiera, estructura de capital, compañía americana. 


\section{Introduction}

The premises behind the use of hybrid financial instruments continue to be the subject a number of research papers. The key problem consists in selecting a convertible debt rather than a traditional issuing of shares of stock or bonds. A review of the analyses carried out up to now leads us to conclude that such decisions are usually motivated by difficulties in raising investment capital. The risk associated with new projects often increases the information asymmetry between the Board and investors. The conversion of a debt instrument into equity is often the only way available to convince investors and to raise capital for the company. That is why when plans to issue hybrid debt are publicly announced, the company's stock price tends to goes down. ${ }^{1}$ It reflects a critical assessment of the issuer's financial standing in the eyes of investors.

The potential of raising capital despite experiencing financial difficulties highlights the appeal of hybrid debt, especially when the difficulties are unrelated to business performance, e.g., the period in 2008 when the financial crisis broke out. The sharp fall in prices on the stock market prevented any favorable issuance of stock. The financial difficulties experienced by banks and the decreasing trust in the debt market significantly increased the cost of external financing. Under such circumstances, the issuing of convertible bonds can be especially beneficial as it allows for the issuing of shares at a price that is higher than the current market price and the option to convert means a reduction in coupon payments. On top of that, hybrid debt with early redemption call/put option may improve the position of both the investor and the issuer. It helps them to reduce the financing time if they decide the move is too risky or unprofitable.

This paper aims to analyse the changes in the terms of hybrid financing for US enterprises over the periods before and after the outbreak of the financial crisis in 2008. Unlike most earlier literature, which analyses the financial characteristics of the issuers (Bancel and Mittoo, 2004; Xiaodan and Huixin, 2009; Chemmanur and Simonyan, 2010; Dong et al., 2012), this paper examines changes in the basic characteristics of issued convertible bonds. Special attention is paid to the impact of the early redemption call/put option on such changes. The hypothesis adopted for the paper is that the option increases the appeal of hybrid financing. Despite a seemingly specialist subject, the paper de facto adds one more voice into a discussion that has been going on for several decades now, namely the optimal capital structure and the problems of effective financing of business. Literature often discusses the financial circumstances surrounding the issuance of convertible bonds. However, only a few publications explore elements of these instruments as determinants of financing

\footnotetext{
${ }^{1}$ The problem is broadly discussed in literature and referred to as the announcement effect. (See: Dann and Mikkelson, 1984; Mehta and Khan, 1995; Lee and Loughran, 1998;Ammann et al., 2006; Loncarski et al., 2008).
} 
possibilities. The aim of this paper is to expand global acquis in this respect. Its contribution to science consists of analyzing the components of issued convertible bonds under rapidly changing macroeconomic circumstances. Such an approach to hybrid financing has not so far been examined in any great detail.

\section{Theoretical premises behind the use of the call/put option in hybrid financing}

Theoretical achievements that focus on the issuing of convertible bonds are rather rich and are based on several groups of concepts. The most prominent of these are the issues involving information asymmetry, according to which there is a continuous difference in the growth potential assessment by shareholders and by the Board, whereby the issuing of convertible bonds is motivated by difficulties in raising capital through the traditional channels. Namely, the effect of excess risk of bankruptcy or the fear of stock watering (Myers and Majluf, 1984). In the opinion of the proponents of the risk shifting concept, the gap in measured risk levels, even if estimates by both parties are far from being real values, hinders traditional financing (Kleidt and Schiereck, 2009). Under such circumstances, premises for the issuing of hybrid debt emerge and they are stronger the higher the investors' uncertainty concerning nonestimated investment risk. Thus, the issuing of convertible bonds means the Board wishes to hide the difficulties faced in raising funding using the traditional channels and this is turn is negatively perceived by investors (Constantinides and Grundy, 1998). These difficulties can be measured with the change in the conversion ratioits increase reflects the reduction in issuer's profits (Kim, 1990). The issuing of hybrid debt, however, makes it possible to lower the interest rate on bonds or to offer shares at prices higher than the market price (Brennan and Schwartz, 1980; Altman, 1989), which seems particularly important in these times of financial crisis. The possibility of conversion facilitates changes in the capital structure that will protect the business against bankruptcy in the case of an investment failing. The company may also use conversion to reduce debt and, by the same token, increase debt capacity (Lewis and Verwijmeren, 2011).

In accordance with the assets substitution hypothesis, an enterprise may issue a convertible debt to mitigate the conflict between owners and creditors (Green, 1984). The conflict results from shareholders' propensity to increase debt due to asymmetric distribution of benefits and risks involved in a given investment. Successful investment produces a higher rate of return to shareholders than to the creditors. When an investment is unsuccessful, shareholders only loose the equivalent of the drop in the stock price while creditors risk all their invested capital (Jensen and Meckling, 1976). If share prices are high, conversion is likely so shareholders are unwilling to take 
additional risk so as not to loose the benefits resulting from the increase in the company's value. It "protects" creditors against excessive risk. Hence, the issuing of convertible bonds is especially justified when the valuation of the company is low, e.g., during the crisis in the stock market.

According to the back-door equity hypothesis, the premise behind the issuing of a hybrid debt is the need to issue shares under conditions which make it unprofitable, e.g., in times of bust (Stein, 1992). The use of a debt component in a hybrid instrument allows financing to be managed in difficult times. The conversion price being higher than the market price helps the issuer avoid the purchase of stock by undesired investors and may protect against a takeover (Zeidlera et al., 2012). The issuance of straight debt in times of crisis may stimulate the risk of bankruptcy. That is why convertible bonds may solve the problem of financing by combining the issuance of shares and bonds under much more favorable conditions (Zwiebel, 1996). The studies most often stress that convertible bonds help adjust the type of financing to the situation of the enterprise in question (Lewis et al., 1999; 2003). Enterprises awaiting their own financing design instruments more "equity-like" than "debt-like" hoping for conversion to take place. Such an approach remains in opposition to the agency theory, according to which enterprises will use preferential debt financing as long as possible.

Premises to issue convertible bonds with the early redemption call/put option are often analysed together with the issuance of a traditional hybrid debt, hence many surveys, e.g., Stein's theory (Stein, 1992), make references to both groups of instruments. Many authors primarily focus, however, on extended hybrid debt to highlight the general advantages of this form of financing. In their opinion, convertible bonds without the option that forces investors to go for conversion would not mitigate the negative consequences of information asymmetry or conflicts among managers, shareholders and bond holders (Mayers, 1998; Isagawa, 2000). Studies confirm that earlier debt redemption may help enterprises avoid financial difficulties (Ekkayokkaya et al., 2012). These difficulties, however, are internal in nature as the issuing of convertible bonds with the call option is characteristic of companies in a relatively poor economic situation, which may estimate the profitability of planned investment projects inaccurately. Firms with a stable financial standing issue convertible bonds and ordinary bonds as they will have no problems with buying them back upon maturity. It confirms Stein's considerations (Stein, 1992), and may refer to times of crisis when, due to rapid changes in demand, estimating the profitability of an investment is very difficult.

When hybrid debt is used by a company to finance investments, and the early redemption option is aimed at conversion, so when conversion becomes feasible, the issuing of convertible instruments is motivated by the wish to gain additional benefits 
for the company that would be unattainable using traditional capital generation methods. The absence of the call/put option could make the conversion more difficult if any threats emerged in the business environment. The economic situation in the stock market is a risk factor in this case. Under high stock market volatility, the ability to carry out conversion at an earlier date increases its likelihood. Analyses show that the issuing of convertible bonds and the following call for conversion aim, first of all, to raise equity, which is again confirmed by Stein's backdoor-equity financing hypothesis (King and Mauer, 2014). The presence of the call/put option restricts risk shift by shortening the maturity period of convertible debt (Barnea et al., 1980).

In general, the studies stress that the issuing of bonds with the call option contains information that is valuable in the enterprise environment. The early redemption of hybrid debt sends a negative signal to the market as it suggests potential difficulties in buying the debt back in the future (Nyborg, 1995). That explains the often negative response of investors when they learn about the scheduled issuing of such instruments (Grundy et al., 2014). Enterprises often exercise aggressive information policy vis-àvis creditors. Financial hardships, however, may prevent them from buying the debt back. Under such circumstances, investors may be forced to accept conditions imposed on them. The refusal to convert may imply an issuer's liquidity crisis. Conversion below the conversion price is unprofitable to the investor but offers the potential of benefiting from possible future profits. This is how managers shift investment risk to the investors. The surveys also highlight the role of issuer's credit risk (Rosengren, 1993; Indro et al., 1999). Increasing the risk of bankruptcy results in reduced prices of convertible bonds. That is why the Board wishes the conversion to take place by exercising the call option.

In terms of cash, the signal that triggers early redemption comes from a situation when dividend from shares issued as a result of conversion is higher than coupon payments (Asquith and Mullins, 1991). Theoretically, this is when investors should aim for conversion (Constantinides and Grundy, 1987). In times of crisis, increased profitability, decisive for the increase in dividend, may be difficult to achieve. The problem might be solved by a new restructuring investment that could reduce the impact of the crisis. The call/put option may then facilitate financing and holding investors hostage during the undertaking. Should it fail, they would prefer to take up shares in the company rather than try to collect on amounts due from a bankrupt debtor. Nevertheless, companies often try to avoid such a solution by delaying early conversion (Emery et al., 1989). The studies also point out that more risky enterprises facing liquidity problems will delay early conversion until a point in time when it is the most likely and has been approved by investors (Jaffee and Shleifer, 1990). High volatility of stock prices and low liquidity are two important determinants of early debt redemption. Both favor delaying early conversion and both seem to emerge in times of financial crisis. 
Furthermore, we need to bear in mind that the interest rate on convertible bonds is usually lower than that of coupon bonds so coupon payments are easily replaceable with even small dividends. If, however, the dividend offered by a company is significantly lower than coupon payments after tax and managers have still not decided in favor of redemption, the market will take this as a positive signal suggesting potential increase in cash flow and dividend in the future (Cambell et al., 1991). However, when a firm, acting in its own interest, exercises the call option, the market may interpret this as potential decrease in the two. The above relationship may be thus used for sending a positive signal, which is so important in these times of crisis.

The reasons behind the issuing of bonds with the call/put option can be explained on the grounds of the agency theory or information asymmetry but one cannot exclude tax-driven motivation (Jalan and Barone-Adesi, 1995). Using the early redemption option an enterprise specifies for how long it is going to benefit from the tax shield (Sarkar, 2003). Forced conversion at an attractive stock price will additionally allow one to avoid liability buyout. Thus, the call option offers more possibilities to manage finance with a view to maximize shareholders assets. Early debt redemption will take place when benefits of the tax shield are lower than shareholders wealth lost due to lower market valuation (Mikkelson, 1981).

In summary, most literature that tackles the reasons behind using convertible bonds, both plain vanilla and enhanced, highlight their role under conditions of difficult access to traditional financing. One should note, however, that the authors identify internal sources of problems faced by enterprises covered by the studies. Literature rarely addresses the problem of components of bonds in the context of circumstances of the issuance. The problem was taken up by Miller and Rock (1985) and Yaman (2010), however, their attention focused exclusively on the relationship between the value of the issuance and financial performance as well as companies' indebtedness. Goh and Xie (2009), in turn, notice the complexity of the structure of convertible bonds, nevertheless, they do not study the potential relationship between the price of conversion, conversion ratio or the time to maturity and macroeconomic circumstances surrounding the issuance hybrid debt. This area has never been thoroughly examined in global literature. Studies to date only allow us to identify basic premises behind the issuance of convertible bonds that result from issuer's internal characteristics. Little do we know about the impact of economic situation upon the structure of convertible bonds. This paper atttempts to analyse the use of convertible bonds in situations when difficulties experienced by a given operator originate in its environment and are linked to the economic situation. We can easily observe that, regardless of the source of the difficulties, the consequences are the same. In the case of external problems, the level of information asymmetry may be lower since neither managers nor investors have materially in-depth knowledge about 
the risk to the operator in question. We may thus assume that a successful issuance of convertible bonds is a sign of economic consensus reached by the two groups.

\section{Sample characteristics}

The study is based on a sample of issuances of convertible bonds exchangeable to equity by American enterprises from non-financial sectors. The selection was primarily limited by the size of the convertible bond market in the United States, resulting in a minimum research sample. The aim of the study is to evaluate how financing with the hybrid debt evolved under times of turbulent changes in the economic situation in the financial market. This is why all identified issuances were divided into two groups: the first one included issuances, which took place before 2008 and the second one all those exercised after 2008. September 2008, when the American investment bank Lehman Brothers announced its insolvency, effectively putting an end to the global boom in the stock markets, was taken as the turning point and the outbreak of the financial crisis. Issuances dated in 2008 were excluded from the study. That was due to an inability to identify the circumstances surrounding them. Some of them could have been planned earlier and were carried out under circumstances that normally would have prevented them from happening. The period before the crisis included 212 issuances over the years 20022007, among which 134 had the earlier redemption option and 78 did not. The sample from the period following the outbreak of the crisis consisted of 238 issuances in the years 2009-2011; 150 out of them had the call/put option and 88 did not.

The study focused on the basic characteristics of the features of convertible bonds, such as: the maturity period of unconverted debt, time from the issuance date until the first possible conversion date, time until the end of possible conversion and the period over which early redemption call/put option can be exercised. In addition, we analysed fluctuations in the conversion ratio, the conversion premium being the surplus in the conversion price over current valuation of company's stock, and interest rate premium. The latter is expressed as the surplus of average weighted cost of issuer's debt capital vis-à-vis coupons offered in convertible bonds.

All data comes from the Bloomberg database. Selected features were analysed in groups of bonds with and without the call/put option. All time-related variables are expressed in days. Furthermore, we took account of the conversion ratio on the issuance day and relative difference between the price of bonds on the issuance day and the conversion price, which helped to identify the conversion premium on the issuance day. The conversion ratio is expressed in times, while conversion premium and interest premium in percentages. The basic statistical characteristics of selected features of convertible bonds are presented in Table 1. 
Table 1. Statistical descriptives of analysed conventional convertible bonds (CB) and convertible bonds with the call/put option (CALL/PUT)

\begin{tabular}{lrrrrr}
\hline Variable & $\begin{array}{c}\text { Arithmetic } \\
\text { average }\end{array}$ & $\begin{array}{c}\text { Standard } \\
\text { deviation }\end{array}$ & Median & Skewness & Kurtosis \\
\hline Period from issuance to conversion's beginning for CBs & 85.120 & 578.814 & 0.000 & 9.889 & 98.022 \\
\hline Period from issuance to conversion's beginning for CALL/PUTs & 62.810 & 226.958 & 0.000 & 5.792 & 36.213 \\
\hline Period from issuance to conversion's end for CBs & 6221.510 & 3124.982 & 7292.500 & 0.147 & -1.028 \\
\hline Period from issuance to conversion's end for CALL/PUTs & 3177.290 & 2766.177 & 2192.000 & 1.837 & 2.170 \\
\hline Buyback period for CBs & 3619.665 & 1985.216 & 3320.500 & 3.236 & 10.751 \\
\hline Buyback period for CALL/PUTs & 2257.384 & 1521.192 & 2202.000 & 4.417 & 21.686 \\
\hline Call period & 3073.488 & 2885.176 & 1803.644 & 3.236 & 10.751 \\
\hline Conversion ratio for CBs & 70.275 & 414.761 & 33.994 & 15.717 & 250.781 \\
\hline Conversion ratio for CALL/PUTs & 476.804 & 2013.009 & 46.847 & 8.590 & 90.296 \\
\hline Conversion premium for CBs (in \%) & 31.870 & 15.887 & 32.226 & 1.992 & 5.629 \\
\hline Conversion premium for CALL/PUTs (in \%) & 28.965 & 10.311 & 27.500 & 1.553 & 4.299 \\
\hline Interest premium for CBs (in \%) & -0.230 & 1.986 & -0.943 & 0.091 & 0.518 \\
\hline Interest premium for CALL/PUTs (in \%) & -2.625 & 3.040 & -1.635 & -0.888 & 2.235 \\
\hline
\end{tabular}

SOURCE:THE AUTHOR'S CALCULATIONS BASED ON BLOOMBERG.

Most of these variables are volatile (standard deviation is many times bigger than the arithmetic average) while skewness ratio and kurtosis go significantly beyond the allowable range $[-1 ; 1]$. That is particularly true of the time from issuance to the first day of conversion and the time to maturity. The above is the effect of atypical values of these variables as issued bonds included some with a very long time to conversion from the issuance date. Half of the population of companies allowed for the conversion on the issuance date. Very "unstabilized" distribution of the time from issuance to first day of conversion has made us deploy the time to maturity and conversion period in the analysis. Average time to maturity is ca. 3,619 days with standard deviation of ca. 3,320 days. For call/puts the average time to maturity reaches ca. 2,257 days with the deviation of 2,202 days on average. The value of conversion ratio is highly dispersed, especially for call/puts. Standard deviation exceeds 2,013 with the average of ca. 476 and skewness is higher than 8. For ordinary bonds, the dispersion is not that big although standard deviation exceeds 414 for the average of ca. 70. Slightly smaller changes can be observed for the conversion premium. Although high standard deviation is observed in both groups of bonds, average and median are similar. The smallest dispersion is for the interest premium. Interestingly, both the median and the average are negative, which means that, contrary to common opinion, the interest rate of hybrid debt is higher than the interest rate without the option to convert. 


\section{Methodology}

To assess differences between features of bonds issued before and after the outbreak of the financial crisis in 2008, we used statistical analysis and the significance test for differences. We used the $t$-test for independent samples and Mann-Whitney test. The $t$-test for independent samples was applied to assess the significance of differences between the expected value of quantitative variable in two independent populations. The null hypothesis is $H_{0}: \mu_{1}=\mu_{2}$ against the alternative hypothesis $H_{1}: \mu_{1} \neq \mu_{2}$.

The test is performed with the t-statistics of the following formula (Starzyńska, 2007):

$$
t=\frac{\bar{x}_{1}-\bar{x}_{2}}{\sqrt{\frac{n_{1} S_{1}^{2}+n_{2} S_{2}^{2}}{n_{1}+n_{2}-2}\left(\frac{1}{n_{1}}+\frac{1}{n_{2}}\right)}},
$$

where: $\bar{x}_{1}, \bar{x}_{2}$ - arithmetic mean of the dependent variable for the population before and during the crisis, $S_{1}^{2}, S_{2}^{2}$ - variance of the dependent variable for the population before and during the crisis. The statistics follows a Student's $t$ distribution with $n_{1}+n_{2}-1$ degrees of freedom $(d f)$.

Where the assumption on the homogeneity of the variance was not satisfied, we used a stronger version of the $t$-test (resilient to non-homogenous variances), with the test statistic taking the form of (Rószkiewicz, 2011):

$$
t=\frac{\bar{x}_{1}-\bar{x}_{2}}{\sqrt{\frac{S_{1}^{2}}{n_{1}-1}+\frac{S_{2}^{2}}{n_{2}-1}}},
$$

The statistics follows a Student's- $t$ distribution with the number of the degrees of freedom:

$$
d f=\frac{\left(\frac{S_{1}^{2}}{n_{1}-1}+\frac{S_{2}^{2}}{n_{2}-1}\right)^{2}}{\frac{S_{1}^{4}}{\left(n_{1}-1\right)^{3}}+\frac{S_{2}^{4}}{\left(n_{2}-1\right)^{3}}} .
$$

Differences between populations, i.e. between the expected values of the dependent variable in the compared populations were considered statistically significant if the probability in the $t$-test was lower than the significance level $\alpha$.

When the assumption of normal distribution of the variable was not met, we used Man-Whitney test as an alternative to the $t$-test of independent samples. The test requires at least orderly levels of measuring the dependent variable. The null hypothesis is: $H_{0}: F_{1}=F_{2}$ against $H_{1}: \neq H_{0}$, where $F_{1}$ and $F_{2}$ are the distribution 
functions of the dependent variable in compared populations. If there are no tied ranks in the sample, the test statistic is (Szymczak, 2010):

$$
Z=\frac{U-\frac{1}{2} n_{1} n_{2}}{\sqrt{\frac{1}{12} n_{1} n_{2}\left(n_{1}+n_{2}+1\right)}}
$$

where: $U=n_{1} n_{2}+\frac{n_{1}\left(n_{1}+1\right)}{2}-R_{1}$.

If there are tied ranks in the sample, the test statistic is:

$$
Z=\frac{U-\frac{1}{2} n_{1} n_{2}}{\sqrt{\frac{n_{1} n_{2}}{n(n-1)}}\left(\frac{n^{3}-n}{12}-\sum_{i} \frac{t_{i}^{3}-t_{i}}{12}\right)},
$$

where: $n=n_{1}+n_{2}, t$ - the number of observations tied with a given rank.

In both cases the $Z$ statistic is supposed to follow an approximately normal distribution with parameters 0 and 1 . Since the null hypothesis states that the two independent samples come from populations with the same probability distribution, differences between populations are considered statistically significant if the $p$-value associated with the Mann-Whitney statistics is lower than the significance level $\alpha$.

The second research method was the two-factor analysis of variance. It allows us to analyse a variable expressed in quantitative terms against two factors, i.e., it will help compare the expected value of a bond variable or characteristic depending on the type of the bond (ordinary or enhanced by the call/put option) and the time of the issuance (before or after the crisis). Two-way analysis of variance belongs to the group of parametric methods. It examines the effect of two qualitative factors upon a quantitative variable. The expression of the two-way analysis of variance with an interaction term is as follows (Wiktorowicz, 2014):

$$
y_{i j k}=\mu+\alpha_{j}+\beta_{j}+\gamma_{i j}+\varepsilon_{i j k}
$$

where: $\alpha_{i}$ - the main effect of the first factor, i.e. the impact of the first factor upon the dependent variable assuming constant level of the second factor (tested with $H_{0}: \alpha_{1}=\alpha_{2}=\ldots=\alpha_{k}$ against $\left.H_{1}: \neq H_{0}\right), \beta_{j}$ - the main effect of the second factor, i.e., the impact of the second factor upon the dependent variable assuming constant level of the first factor (tested with $H_{0}: \beta_{1}=\beta_{2}=\ldots=\beta_{j}$ against $H_{1}: \neq H_{0}$ ), $\gamma_{i j}$ - the effect of interaction of the two factors understood to be a combined, 
intrinsically linked impact of both factors on the dependent variable (tested with $H_{0}: \gamma_{11}=\gamma_{21}=\ldots=\gamma_{K J}$ against $\left.H_{1}: \neq H_{0}\right), \varepsilon_{i j k}$ - error.

The analysis of variance requires normal distribution and homogeneity for comparison of the dependent variable from the two populations. Numerous studies show that the F-test for the analysis of variance is rather resistant to deviations from these assumptions, especially when the design of the test is balanced and the distribution of the variable is not extremely asymmetric (Szymczak, 2010; Drummond and Vowler, 2012; Wiktorowicz, 2014). In order to apply the analysis of variance with a strongly right-side asymmetry, the logarithmical transformation of the variables is usually recommended (Szymczak, 2010). For heterogeneous variances, root transformation is recommended (when the means and group variances are proportional) or logarithmical transformations when the squares of means and group variances are proportional (Rószkiewicz, 2011).

For the study, we assumed a standard level of significance $\alpha=0.05$. Calculations were made using IBM SPSS Statistics 22.0.

\section{Results}

The analysis of changes in the characteristics of convertible bonds issued before and after 2008 allows us to state that the financial crisis had a significant impact upon enterprises which financed their operations with a hybrid debt (Table 2). The time period until the conversion date of conventional convertible bonds ( $C B$ ) shortened by 18 days while for bonds with the call/put option (C/P) it shortened by 30 days. In both cases the median was 0 meaning the conversion was feasible immediately upon the issuance for at least half of issuances included in the study. The volatility of this variable in both groups of instruments was also reduced. It is worth noting that in both periods, the time until the date of conversion is longer for CB than for C/P. After 2008 the change in the time until the date of conversion is higher for the C/P. However, we need to stress the lack of significance of the differences tested in both groups of bonds.

Bonds issued after the crisis had a shortened maturity period. For CBs the time was shorter on average by 2,646 days, i.e., by ca. $40 \%$. C/P bonds were offered with the maturity period shorter by 1,784 days. We need to note, however, a significant differentiation in both groups of observations, which is confirmed by the median. Its changes are analogous to those of the mean. For C/P the maturity (call) period was shortened, but to a lesser degree. Also the changeability of observations was smaller for the group after 2008 . 
Table 2. Maturity periods for traditional hybrid debt (CB) and for convertible bonds with the call/put option before and after the financial crisis of 2008 (in days)

\begin{tabular}{|c|c|c|c|c|c|}
\hline Variable & Moment of issuance & Mean & Median & Standard deviation & $\mathrm{p}$ \\
\hline \multirow{2}{*}{$\begin{array}{l}\text { Period from issuance to } \\
\text { conversion's beginning for CBs }\end{array}$} & before 2008 & 83.46 & 0 & 539.21 & \multirow{2}{*}{0.279} \\
\hline & after 2008 & 65.02 & 0 & 232.92 & \\
\hline \multirow{2}{*}{$\begin{array}{l}\text { Period from issuance to } \\
\text { conversion's beginning for CALL/PUTs }\end{array}$} & before 2008 & 85.35 & 0 & 422.63 & \multirow{2}{*}{0.371} \\
\hline & after 2008 & 55.01 & 0 & 188.32 & \\
\hline \multirow{2}{*}{ Buyback period for $\mathrm{CBs}$} & before 2008 & $6,197.38$ & $7,321.64$ & $3,179.11$ & \multirow{2}{*}{$<0.001^{\star}$} \\
\hline & after 2008 & $3,551.11$ & $2,211.15$ & $2,701.43$ & \\
\hline \multirow{2}{*}{ Buyback period for CALL/PUTs } & before 2008 & $6,481.72$ & $7,691.14$ & $2,941.28$ & \multirow{2}{*}{$<0.001^{*}$} \\
\hline & after 2008 & $4,697.15$ & $3,451.89$ & $2,522.39$ & \\
\hline \multirow{2}{*}{$\begin{array}{l}\text { Period from issuance to } \\
\text { conversion's end for CBs }\end{array}$} & before 2008 & $6,214.12$ & $7,382.29$ & $3,196.69$ & \multirow{2}{*}{$<0.001^{\star}$} \\
\hline & after 2008 & $3,179.59$ & $2,200.2$ & $2,828.16$ & \\
\hline \multirow{2}{*}{$\begin{array}{l}\text { Period from issuance to } \\
\text { conversion's end for CALL/PUTs }\end{array}$} & before 2008 & $6,325.19$ & $7,414.09$ & $2,260.11$ & \multirow{2}{*}{$<0.001^{\star}$} \\
\hline & after 2008 & $4,113.54$ & $3,991.31$ & $5,983.38$ & \\
\hline \multirow{2}{*}{ Call period } & before 2008 & $3,621.54$ & $3,329.9$ & $1,989.36$ & \multirow{2}{*}{$<0.001^{*}$} \\
\hline & after 2008 & $2,251.41$ & $2,218.09$ & $1,525.07$ & \\
\hline
\end{tabular}

$p$ - probability in the $t$-test or in the Mann-Whitney test.

* - statistically significant differences $(\alpha=0.05)$.

SOURCE:THE AUTHOR'S CALCULATIONS BASED ON BLOOMBERG.

The time until the end of conversion was also shortened. For CB bonds after the crisis, the period shortened by 3,034 days, meaning it was significantly shorter, similar to the maturity. In the C/P group, the period was shortened by 2,211 days and it is also a statistically significant reduction. The time until the end of conversion is strongly differentiated before and after the crisis. While in the case of CBs, the volatility is not high, in the C/P group it is significant. Interestingly, after 2008 the volatility of the period until the end of conversion increased for the $C / P$ contrary to the maturity period. Both features are higher compared to the $C B$ bonds but they are more biased with extreme values.

Finally, the comparison of early redemption period of debt allows us to note that after the outbreak of the crisis, call/put options were offered for shorter periods. The period was shortened on average by 1,370 days (median 1,111 days), with relatively few significant outliers. This is in line with the tendency observed for previously analysed features, which is yet more evidence of the shortening of hybrid financing periods after 2008 .

When analyzing other components of the structure of convertible bonds (Table 3), we observe that for both groups of bonds, $C B$ and call/put, conversion ratios significantly increased after the outbreak of the financial crisis. Observed ratios are strongly differentiated, which can be seen by the significant differences between the mean and the median and by the standard deviation. Volatility intensifies after 2008. While for CB bonds the differences are statistically significant, the same cannot be said for the second group studied. 
Table 3. Characteristics of traditional hybrid debt (CB) and of convertible bonds with call/put option before and after the financial crisis of 2008

\begin{tabular}{|c|c|c|c|c|c|}
\hline Variable & Moment of issuance & Mean & Median & Standard deviation & $\mathrm{p}$ \\
\hline Conversion ratio for $\mathrm{CBs}$ & $\begin{array}{c}\text { before } 2008 \\
\text { after } 2008\end{array}$ & $\begin{array}{c}78.89 \\
488.79\end{array}$ & $\begin{array}{l}35.23 \\
50.02\end{array}$ & $\begin{array}{c}420.09 \\
2027.14\end{array}$ & $<0.001^{\star}$ \\
\hline Conversion ratio for CALL/PUTs & $\begin{array}{l}\text { before } 2008 \\
\text { after } 2008\end{array}$ & $\begin{array}{c}66.14 \\
297.27\end{array}$ & $\begin{array}{l}38.28 \\
55.43\end{array}$ & $\begin{array}{c}295.38 \\
3093.18\end{array}$ & 0.112 \\
\hline Conversion premium for $\mathrm{CBs}$ & $\begin{array}{c}\text { before } 2008 \\
\text { after } 2008\end{array}$ & $\begin{array}{l}33.18 \\
30.94\end{array}$ & $\begin{array}{l}36.13 \\
29.01\end{array}$ & $\begin{array}{l}16.96 \\
11.37\end{array}$ & 0.151 \\
\hline Conversion premium for CALL/PUTs & $\begin{array}{c}\text { before } 2008 \\
\text { after } 2008\end{array}$ & $\begin{array}{l}39.08 \\
35.88\end{array}$ & $\begin{array}{l}40.99 \\
33.36\end{array}$ & $\begin{array}{c}9.03 \\
12.88\end{array}$ & $<0.001^{*}$ \\
\hline Interest premium for $\mathrm{CBs}$ & $\begin{array}{c}\text { before } 2008 \\
\text { after } 2008\end{array}$ & $\begin{array}{l}-0.21 \\
-2.74\end{array}$ & $\begin{array}{l}-0.89 \\
-1.49\end{array}$ & $\begin{array}{l}1.71 \\
2.83 \\
\end{array}$ & $<0.001^{\star}$ \\
\hline Interest premium for CALL/PUTs & $\begin{array}{c}\text { before } 2008 \\
\text { after } 2008\end{array}$ & $\begin{array}{l}0.57 \\
-1.31\end{array}$ & $\begin{array}{l}-0.07 \\
-0.31\end{array}$ & $\begin{array}{l}1.81 \\
2.39\end{array}$ & $<0.001^{\star}$ \\
\hline
\end{tabular}

$p$ - probability in the $t$-test or in the Mann-Whitney test.

* - statistically significant differences $(\alpha=0.05)$.

SOURCE:THE AUTHOR'S CALCULATIONS BASED ON BLOOMBERG.

After the outbreak of the crisis, we noted the decrease in the conversion premium. It was particularly obvious in the group of $\mathrm{C} / \mathrm{P}$ bonds (average drop by $3.2 \mathrm{pP}$ ) compared to $\mathrm{CB}$ (average drop by $2.24 \mathrm{pp}$ ). The change in the median for $\mathrm{C} / \mathrm{P}$ after 2008 is smaller than before the outbreak of the crisis (7.63 pp against 7.12 pp). However, in both groups of bonds we observed significantly different changes in standard deviation. It may imply that the issuance of bonds with the call/put option enabled the stating of a higher conversion price, which under less favorable situation in the stock markets could be perceived as a serious advantage, but is strongly dependent on each individual cases. It should also be noted that for CBs, the differences are not statistically significant.

In most cases, $\mathrm{CB}$ issuers did not get the interest premium; before the crisis the phenomenon was observed for the $\mathrm{C} / \mathrm{P}$ bonds (not confirmed by the median). It should be noted, however, that lower coupon premium is on average smaller for C/Ps (drop by $1.88 \mathrm{pp}$ ) than for traditional CBs (drop by $2.53 \mathrm{pP}$ ). Similarly, from the change in median, we observe the $0.6 \mathrm{pp}$ drop for $\mathrm{CBs}$ against the $0.24 \mathrm{pp}$ drop for $\mathrm{C} / \mathrm{P}$ coupon premium. The variable also exhibits lower volatility in the $\mathrm{C} / \mathrm{P}$ group after the crisis.

Figure 1 presents the average levels of individual components of issued convertible bonds taking into account two factors: the type of bond and the date of issuance (before or after 2008), using two-way variance analysis. As already shown in earlier analyses, individual characteristics of the issuance differed for the two sub-periods. Furthermore, Figure 1 confirms the importance of the interaction effect of the two factors; differences between $\mathrm{CB}$ and call/put bonds take a significantly different course in 2002-2007 than in 2009-2011. If curves for individual groups (here: bonds issued 
Figure 1. Characteristics of the issuance of bonds by types of bonds and issuance date

Period until conversion $(p=0.236)$

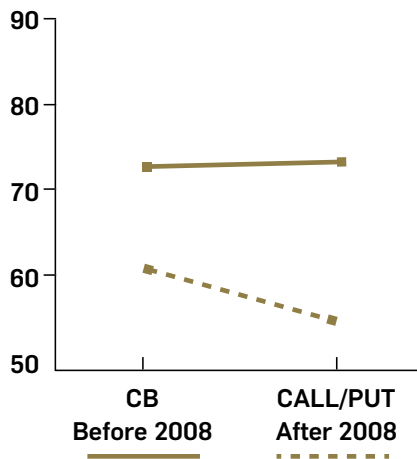

Period until the end of conversion $(p<0.001)^{*}$

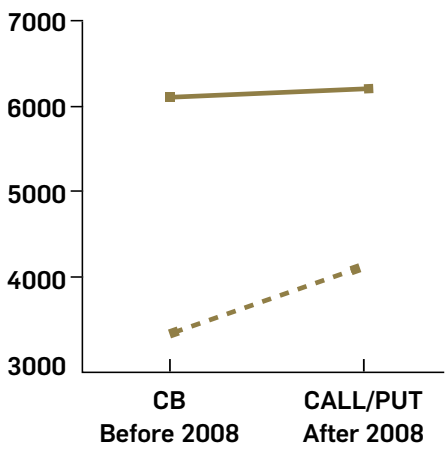

Conversion premium $(p=0.018)^{*}$

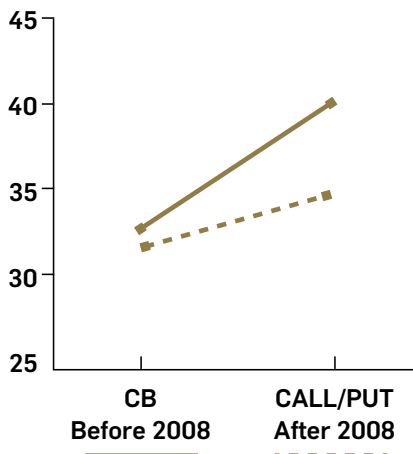

Debt maturity period $(p=0.030)^{*}$

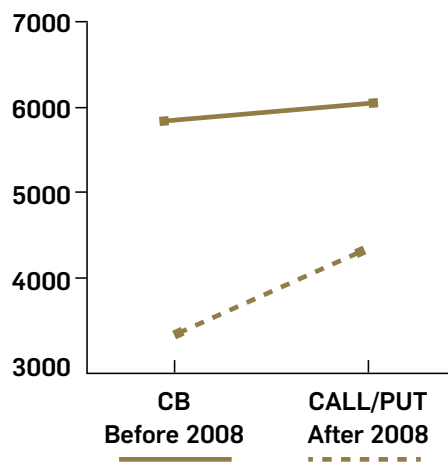

Conversion ratio $(p=0.069)$

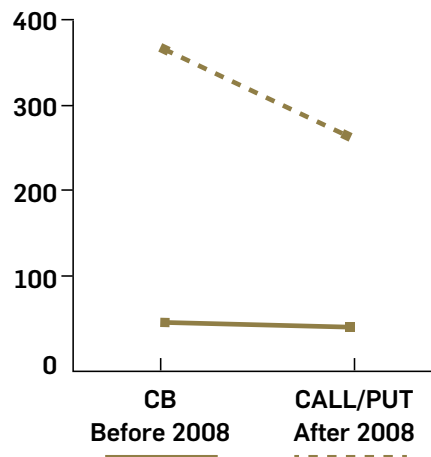

Coupon premium $(p=0.003)^{\star}$

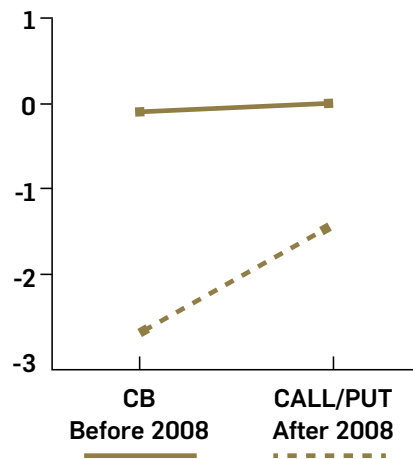

$p$ - probability in the $t$-test or in the Mann-Whitney test.

* - statistically significant differences $(\alpha=0.05)$.

SOURCE:THE AUTHOR'S CALCULATIONS BASED ON BLOOMBERG. 
before and after the crisis) converge or cross, that is indicative of the interaction effect. Additionally, above each figure there is $\mathrm{p}$ in F-test analyzing interaction effect in ANOVA. Null hypothesis assumes there is no interaction effect, thus $p<$ alpha allows us to consider the interaction effect as being statistically significant, meaning for individual variable differences between $\mathrm{CB}$ bonds and other bonds differ for bonds issued before and after crisis. This is true for most issuance characteristics (with the exception of the period until conversion and the conversion ratio). Similarly to the analysis of differences, we observe decreases in all characteristics except the conversion ratio (dotted line). The variable is the most differentiated when we compare the situation before and after the outbreak of the crisis. It increased much more for convertible bonds. Big changes were also reported for debt maturity period and the period until the end of conversion. Significant shortening of both periods is, however, smaller for the bonds enhanced by the early redemption call/put option. For the call/put group, the coupon premium is also less negative in the period after the outbreak of the crisis. The study has not confirmed, however, the absence of benefits related to the allegedly lower interest rate on convertible bonds compared to traditional debt. Issuers had to offer a higher rate of return to investors. Conversion premium is the component, which remained relatively stable after 2008. For ordinary CB bonds, the reduction in premium is smaller. Call/put bonds after the crisis were issued with a significantly lower premium, nevertheless, we must remember that before 2008 the premium was significantly higher. Its reduction in 2008 took it back to the average level slightly higher than those for ordinary CBs before the crisis. That is indicative of better conditions for financing offered by bonds extended with the call/put option against traditional hybrid debt.

\section{Conclusions}

The analysis presented above unambiguously identifies changes in hybrid financing during this period of financial crisis. The worsening of financing conditions is of particular note. The average maturity time for bonds and the period of conversion have been tangibly shortened, and that is true of both groups of bonds. It is indicative of difficulties in using convertible bonds and likely investor concerns linked to the problems faced by enterprises in achieving valuations that would enable the conversion. These concerns are visible in the likelihood of immediate conversion upon the issuance of shares, the possibility signaled by zero median for the period at the beginning of the conversion. It should be noted, however, that in the group of bonds extended with call/put option, the shortening of the maturity or conversion periods is smaller. That can be explained by the ability to shorten investor's position when he/she decides that engagement is too risky or ineffective. The results suggest the option of earlier redemption was approved by investors who agreed to a longer investment or conversion periods. Data in Table 2 demonstrate 
that on average early redemption period accounted for $30 \%$ of the maturity period. Clearly, difficulties in the financial market after 2008 shortened the time of potential exercising of the call/put option but it still seems to be a remedy for financing in difficult times. Convertible bonds extended using such an option seem less sensitive to crisis.

The events of 2008 also influenced the conversion ratio, namely by significantly increasing it. This can be explained by less favorable valuations in the stock market, which greatly hindered the conversion. The increased population of shares available under the conversion arrangement increases the potential profit of the investor. However, it should be noted that the value of the conversion ratio is highly dependent on the share price. Increases observed after 2008 may be due to the fact that issuances were made by companies with a low unit share price.

Conversion premium does not raise such concerns. Convertible call/put bonds have a higher conversion rate for both groups. Conversion to shares was possible at rates higher than the present ones. Instruments from this group suffered less from the crisis, although the latter still managed to exert a negative impact. The early redemption option opened the way to more attractive financing compared to the traditional hybrid debt. Similar conclusions can be reached following analysis of the interest premium. In this case, the coupon also increases after 2008, however, the increase is smaller with the call/put group.

In light of the above observations, it can be noted that the early redemption option attached to a hybrid debt improves the financing of the issuer under less favorable conditions in the capital market. Hence, no grounds have been identified to reject the initial hypothesis. Financial crisis increases investor risk. Furthermore, information asymmetry is bigger. The call/put option mitigates tension between the issuer and the investors. It is the outcome of the potential ability to shorten the time of acting as a creditor. Benefits seem to be mutual: a company enjoys better financing terms, which obviously is not beneficial for investors, but the latter acquire additional liquidity of their assets. These benefits are expressed by the difference between traditional hybrid debt and a hybrid debt with an early redemption option. The study also seems to confirm the findings of research that examines the premises behind the issuing of convertible bonds as a remedy when there are difficulties with traditional financing. 


\section{References}

Altman, E.I. (1989). The Convertible Debt Market: Are Returns Worth the Risk?, Financial Analysts Journal, 45(4), pp. 23-31.

Ammann, M., Fehr, M. and Seiz, R. (2006). New evidence on the announcement effect of convertible and exchangeable bonds, Journal of Multinational Financial Management, 16, pp. 43-63.

Asquith, P. and Mullins, D. (1991). Convertible debt: corporate call policy and voluntary conversion, Journal of Finance, 46, pp. 1273-1289.

Bancel, F. and Mittoo, U.R. (2004). Why Do European Firms Issue Convertible Debt?, European Financial Management, 10(2), pp. 339-373.

Barnea, A., Haugen, R.A. and Senbet, L.W. (1980). A rationale for debt maturity structure and call provisions in the agency theoretic framework, Journal of Finance, 35, pp. 1223-1234.

Brennan, M.J. and Schwartz, E.S. (1980). Analyzing convertible bonds, Journal of Financial and Quantitative Analysis, 15, pp. 907-929.

Campbell, C.J, Ederington, L.H. and Vankudre, P. (1991). Tax Shields, Sample-Selection Bias, and the Information Content of Conversion-Forcing Bond Calls, Journal of Finance, 46(4), pp. 1291-1324.

Chemmanur, T.J. and Simonyan, K. (2010). What Drives the Issuance of Putable Convertibles: Risk-Shifting, Asymmetric Information, or Taxes?, Financial Management, 39(3), pp. 1027-1067.

Constantinides, G.M. and Grundy, B.D. (1989). Optimal investment with stock repurchase and financing as signals, Review of Financial Studies, 2(4), pp. 445-465.

Dann, L. and Mikkelson, W. (1984). Convertible debt issuance, capital structure change and financing-related information: some new evidence, Journal of Financial Economics, 13, pp. 157-186.

Dong, M., Dutordoir, M. and Veld, C. (2012). Why do firms issue convertible bonds? Evidence from the field, Manchester Business School Working Papers Series, SSRN, Available at: http://papers.ssrn.com/sol3/papers.cfm? abstract_id=1908476.

Drummond, G.B. and Vowler, S.L. (2012). Analysis of variance: variably complex, Journal of Physiology, 590, pp. 1303-1306.

Ekkayokkaya, P., Gemmill, G. and Koufopoulos, K. (2012). Why are Some Issues of Convertibles Callable and Others Not? SSRN, Available at: http://papers.ssrn.com/sol3/papers.cfm?abstract_id=2158237.

Emery, D.R., Iskandar-Datta, M.E. and Rhim, J.C. (1994). Capital structure management as a motivation for calling convertible debt, Journal of Financial Research, 17, pp. 91-104.

Goh, J. and Xie, W. (2009). Is Convertible Bond Offering a Backdoor Equity Offering?, Electronic resource: http://citeseerx.ist.psu.edu/viewdoc/summary?doi=10.1.1.187.2343.

Green, R.C. (1984). Investment Incentives, Debt, and Warrants, Journal of Financial Economics, 13, pp. 115-136.

Grundy, B.D., Veld, C., Verwijmeren, P. and Zabolotnyuk, Y. (2014). Why are conversion-forcing call announcements associated with negative wealth effects?, Journal of Corporate Finance, 24, pp. 149-157. 
Indro, D.C., Leach, R.T. and Lee, W.Y. (1999). Sources of gains to shareholders from bankruptcy resolution, Journal of Banking and Finance, 23, pp. 21-48.

Isagawa, N. (2000). Convertible debt: an effective financial instrument to control managerial opportunism, Review of Financial Economics, 9(12), pp. 15-26.

Jaffee, D. and Shleifer, A. (1990). Costs of financial distress, delayed calls of convertible bonds, and the role of investment banks, Journal of Business, 63, pp. 107-123.

- Jalan, P. and Barone-Adesi, G. (1995). Equity financing and corporate convertible bond policy. Journal of Banking and Finance, 19(2), pp. 187-206.

Jensen, M.C. and Meckling, W.H. (1976). Theory of the Firm: Managerial Behavior, Agency Costs and Ownership Structure, Journal of Financial Economics, 3, pp. 305-360.

Kim, Y.O. (1990). Informative conversion ratios: A signaling approach, Journal of Financial and Quantitative Analysis, 25(2), pp. 229-243.

King, T-H.D. and Mauer, D.C. (2014). Determinants of corporate call policy for convertible bonds, Journal of Corporate Finance, 24, pp. 112-134.

Kleidt, B. and Schiereck, D. (2009). Systematic risk changes around convertible debt offerings: A note on recent evidence, Global Finance Journal, 20, pp. 98-105.

Lee, I. and Loughran, T. (1998). Performance following convertible bond issuance, Journal of Corporate Finance, 4, pp. 185-207.

Lewis, C.M., Rogalski, R.J. and Seward, J.K. (1999). Is convertible debt a substitute for straight debt or for common equity?, Financial Management, 28, pp. 5-27.

- Lewis, C.M., Rogalski, R.J. and Seward, J.K. (2003). Industry conditions, growth opportunities and market reactions to convertible debt financing decisions, Journal of Banking and Finance, 27, pp. 153-181.

Lewis, C.M. and Verwijmeren, P. (2011). Convertible security design and contract innovation, Journal of Corporate Finance, 17(4), pp. 809-831.

Loncarski, I., Horstand, J. and Veld, C. (2008). Why do companies issue convertible bond loans? An empirical analysis for the Canadian market, Canadian Journal of Administrative Sciences, 25(3), pp. 214-236.

Mayers, D. (1998). Why firms issue convertible bonds: The matching of financial and real investment options, Journal of Financial Economics, 47, pp. 83-102.

Mehta, D. and Khan, Q. (1995). Convertible bond issues: evidence from securities markets, Financial Review, 30, pp. 781-807.

Mikkelson, W.H. (1981). Convertible calls and security returns, Journal of Financial Economics, 9, pp. 237-264.

Miller, M.H. and Rock, K. (1985). Dividend policy under asymmetric information, Journal of Finance, 40, pp. 1031-1051.

Myers, S.C. and Majluf, N.S. (1984). Corporate financing and investment decisions when firms have information that investors do not have, Journal of Financial Economics, 13(2), pp. 187-221.

Nyborg, K.G. (1995). Convertible Debt as Delayed Equity: Forced versus Voluntary Conversion and the Information Role of Call Policy, Journal of Financial Intermediation, 4(4), pp. 358-395. 
Rosengren, E.S. (1993). Defaults of original issue high-yield convertible bonds, Journal of Finance, 48, pp. 345-362.

Ruszkiewicz, M. (2011). Analiza klienta, SPSS, Kraków.

Sarkar, S. (2003). Early and late calls of convertible bonds: Theory and evidence, Journal of Banking and Finance, 27, pp. 1349-1374.

Starzyńska, W. (2007). Statystyka praktyczna, PWN, Warszawa.

Stein, J. (1992). Convertible bonds as backdoor equity financing, Journal of Financial Economics, 32, pp. 3-21.

Szymczak, W. (2010). Podstawy statystyki dla psychologów, Difin, Warszawa.

Wiktorowicz, J. (2014). Modele analizy wariancji w ocenie sytuacji zawodowej osób w wieku 45+, Acta Universitatis Lodziensis Folia Oeconomica, 298, pp. 63-75.

Xiaodan, H. and Huixin, M. (2009). Empirical Study on the Financial Characteristics of Chinese Companies Issuing Convertible Bonds, International Journal of Business and Management, 4(6), pp. 59-64.

Yaman, D. (2010). Convertible Bond Design And Long-Run Operating Performance, The International Journal of Business and Finance Research, 4(3), pp. 17-30.

Zeidlera, F., Mietznerb, M. and Schiereck, D. (2012). Risk dynamics surrounding the issuance of convertible bonds, Journal of Corporate Finance, 18(2), pp. 273-290.

Zwiebel, J. (1996). Dynamic capital structure under managerial entrenchment. The American Economic Review, 86, Academic Research Library, pp. 1197-1215. 